\title{
ÉRINTŐLEGES LÉGVEZETÉSI RENDSZER LÉGMOZGÁSÁNAK MÉRÉSES ELEMZÉSE
}

\section{ANALYSIS OF MEASUREMENTS OF AIR MOVEMENT IN TANGENTIAL AIR SUPPLY SYSTEM}

\author{
Böttger Eszter Réka ${ }^{1}$, Both Balázs ${ }^{2}$ \\ Budapesti Müszaki és Gazdaságtudományi Egyetem, Gépészmérnöki kar, Épületgé- \\ pészeti és Gépészeti Eljárástechnika Tanszék, Cím: H-1111 Budapest, Müegyetem \\ rakpart 3-9. D épület 1. emelet. Telefon: +36 30/830-5068 \\ Ibottger.eszti@gmail.com \\ ²both@epget.bme.hu
}

\begin{abstract}
The presence of draught is an unwanted and unpleasant discomfort parameter in offices, because it can make the working performance low. Furthermore, due to the draught the risk of health problems may be higher and people require higher indoor air temperature which modifies the energy consumption of the building. The international standards and technical reports suggest general values for draught comfort design. However, these values only consider the air distribution type: displacement or mixing and do not take into consider some details. These details are the type and geometry of the air diffuser device, location of the diffuser, inlet air velocity and so on.
\end{abstract}

Keywords: tangential air distribution; draught comfort; single office

\section{Összefoglalás}

A huzathatás jelenléte általános probléma az irodaépületekben, hiszen jelentősen csökkentheti a munkateljesítményt. Ezen kívül növeli a kötőszöveti gyulladások kialakulásának kockázatát, valamint a huzathatás miatt az emberek növelik a belső hőmérsékletet, ami az épület energiafelhasználását is módosítja. A huzathatás jelenléte tehát együttesen energetikai és egészségügyi szempontból is kedvezőtlen. A nemzetközi szabványok és ajánlások különböző huzatkomfort kategóriákhoz tervezési irányértékeket javasolnak. A fő probléma a javaslatokkal azonban az, hogy túl általános, ugyanis a szellőztetési módokat csupán annak alapján különböztetik meg, hogy elárasztásos, vagy pedig hígításos, illetve milyen a helyiség fö rendeltetése. Ezen kívül már nem veszik figyelembe pl. a befúvószerkezet típusát, geometriáját, beépítését, a befúvási sebességet, stb.

Kulcsszavak: érintöleges légvezetési rendszer; huzatkomfort; kisméretü iroda

\section{Vonatkozó szabványok tervezési irányértékei}

A komfort problémák közül a huzathatás a legjelentősebb, elsősorban az irodaépületekben [1]. A CEN CR 1752:2000 ajánlás külön foglalkozik az irodákra vo- natkozó légtechnikai követelményekkel. A huzatérzet modellezésére Európában a Fanger által kidolgozott empirikus modellt alkalmazzák általánosan [2], mely a huzathatás minősítéséhez az ún. DR szubjektív huzatérzeti számot használja. A DR azt mutatja meg, hogy átlagosan hány százalék 
a huzathatással elégedetlenek várható aránya. A huzatkomfortra leginkább az átlagsebesség és a turbulencia intenzitás van hatással, ezért ezek vizsgálatával foglalkoztunk. Egy kisméretü irodahelyiség valós méretű modelljén végeztünk kísérleteket érintőleges légvezetési rendszer alkalmazásával.

A CEN CR 1752 és az ISO 7726 [3] a helyiség tartózkodási zónájában az átlagsebességek irányértékeire a következő javaslatokat teszik.

1. táblázat. Átlagsebességek a tartózkodási zónában, $\mathrm{m} / \mathrm{s}$

\begin{tabular}{|c|c|c|}
\hline Kategória & Nyár & Tél \\
\hline A & 0.18 & 0.15 \\
\hline B & 0.22 & 0.18 \\
\hline C & 0.25 & 0.21 \\
\hline
\end{tabular}

Habár ezek az értékek megengedett átlagsebességek, a gyakorlatban a tervezés során sok esetben ezek alkalmazásával számítják a huzatkomfortot.

A CEN 1752 ajánlás, az ISO 7726 és az MSZ EN 13779 [4] szabvány hígításos légvezetési rendszer alkalmazása esetén $40 \%$, elárasztásos légvezetés esetén $20 \%$ megengedhető turbulencia intenzitást javasol. A légvezetési rendszer típusát, kialakítását nem veszik figyelembe. Légvezetési rendszer alatt a helyiségben belül történő levegőelosztást értjük, amelyet nagyban meghatároz az alkalmazott befúvószerkezet kialakítása és elhelyezése [5]. Kisméretü irodahelyiségekben többnyire érintőleges légvezetési rendszert alkalmaznak egysoros résbefúvóval. Cikkünkben arra szeretnénk rávilágítani, hogy a szabványok által javasolt huzatkomfort tervezési értékeitől jelentős eltérés mutatkozhat.

\section{Mérési elrendezés}

A mérőkamrában alkalmazott érintőleges légvezetési rendszer függőleges befúvás és függőleges elszívás elrendezésủ. A lég- sebesség és a turbulencia intenzitás mérésére forrógömbös méröszondát használtunk, 200 másodperces mintavételezési idővel. A helyiség 29 pontjában végeztük el a méréseket az ISO 7726 [3] szabvány ajánlása alapján négy magasságban: boka $(\mathrm{y}=0.1$ $\mathrm{m})$, derék $(\mathrm{y}=0.6 \mathrm{~m})$, ülő ember fejmagasság $(\mathrm{y}=1.1 \mathrm{~m})$, álló ember fejmagasság $(\mathrm{y}=$ $1.7 \mathrm{~m}$ ). Két beállításban végeztünk el a méréseket a befúvási Reynolds-szám $(\mathrm{Re}=2854 . .3469)$, valamint a befúvó távolsági arányának $(\mathrm{OR}=21.67 . .30 .00$, azaz offset ratio) változtatásával. A távolsági arány a rés faltól mért távolságának és szélességének hányadosát jelenti.

\section{A mérési eredmények vizsgálata}

A mérési eredmények értékeléséhez statisztikai módszereket alkalmaztunk, melyek feltételezik a vizsgált változó normális eloszlását [6]. A normalistásvizsgálat eredményeként azt kaptuk, hogy minden mért mennyiség Gauss-eloszlású $95 \%$-os valószínűségi szinten. A vizsgálatok során a szabvány által javasolt értékek és a mérési eredmények összehasonlítása volt a cél.

Az F-próba eredményeként arra jutottunk, hogy a bokaszinten mért sebességek és turbulencia intenzitások szórása szignifikánsan különbözik a többi szinttől. Ezen kívül a befúvási sebesség és a beépítési távolság növelése nincs hatással az egyes magasságokban kialakuló sebességek, valamint turbulencia intenzitások szórására.

A kétmintás t-próba segítségével megállapítottuk, hogy a mérési magasságokban kialakuló átlagos sebesség és turbulencia intenzitás várható értékei között nincs szignifikáns különbség. A beépítési távolság és a Reynolds-szám változtatása mellett adott magasságban a sebességek, valamint turbulencia intenzitások várható értékei megegyeznek.

Következő lépésben definiáltunk egy ún. sebesség és turbulencia intenzitás mutatót: Velocity Index (VI) és Turbulence 
intensity Index (TuI). Ezek a mutatók azt fejezik ki, hogy az egyes magasságokban mért adatokból számított átlagos sebesség és turbulencia intenzitás hogyan viszonyul a szabványban javasolt értékekhez [7]. Ezen felül definiáltunk egy ún. sebesség eloszlás mutatót is, a Velocity Distribution Index-et (VDI), mely azt mutatja meg, hogy adott magasságban az egyes pontokban mért értékek hány százaléka kisebb, mint a szabvány követelményértéke [7].

A fent definiált mutatók segítségével értékeltük a mérési eredményeket.

\subsection{A VI sebességmutató értékelése}

A VI értékek segítségével jól szemléltethető, hogy a tartózkodási zónában kialakuló átlagsebesség hogyan alakul a szabványban felállított követelményekhez képest [8].

A Reynolds-szám növelésével végzett mérések esetén a VI index egyértelmüen megmutatja, hogy a vizsgált tartományban a kategória függvényében a mért értékek egyre inkább kisebbek a szabványbeli értékhez képest. A befúvási sebesség növekedésével a VI értéke is egyre magasabb (1. ábra).

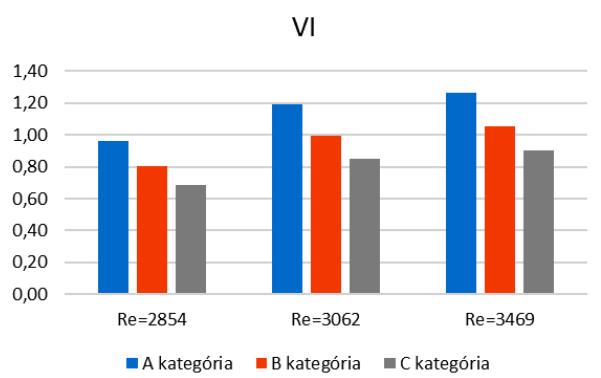

1. ábra. Velocity Index-ek a befúvási Reynoldsszámok mellett

A távolsági arány növelése ehhez hasonló eredményeket hozott. Itt is azt láttuk, hogy a kategória függvényében egyre inkább megfelel a helyiség a követelményeknek. A beépítési távolság növelésével általánosan a VI is növekedett.
U-próbával külön vizsgáltuk azokat a pontokat, amelyeknél a mért érték a szabványos követelmény közvetlen környezetében van. Ezzel arra kerestük a választ, hogy ezek az értékek ténylegesen megfeleltethetők-e a szabványértékeknek. A Reynoldsszám növelése esetén minden esetben negatív eredményt kaptunk, míg a távolsági arány változtatása során kapott mérési adatok és a szabványos értékek között többnyire nincs szignifikáns különbség.

\subsection{Tu I turbulenciafok index}

A Reynolds-szám növelésével végzett kísérletek esetén számított Tu I értékekről nem állapítható meg általános növekvő vagy csökkenő tendencia (2. ábra).

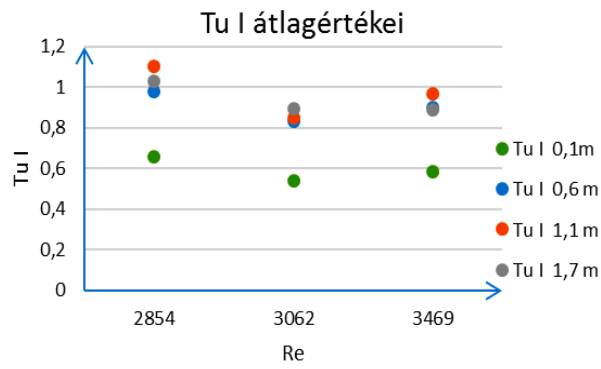

2. ábra. Turbulencia intenzitás index-ek a befúvási Reynolds-számok mellett

Ugyanez elmondható a beépítési távolság változtatása mellett kapott turbulencia indexről [7]. Az u-próba eredményeként minden esetben igaz, hogy a mért értékek megfeleltethetők a követelményértékeknek.

\subsection{VDI sebesség eloszlás mutató}

A VDI mutató segítségével állapítottuk meg, hogy adott mérési magasságban a mérési pontok hány százaléka maradt a szabványban javasolt sebességérték alatt. A befúvási sebesség növelésével azt látjuk, hogy a VDI több-kevesebb eltéréssel átlagosan csökken mindhárom kategória esetén. 


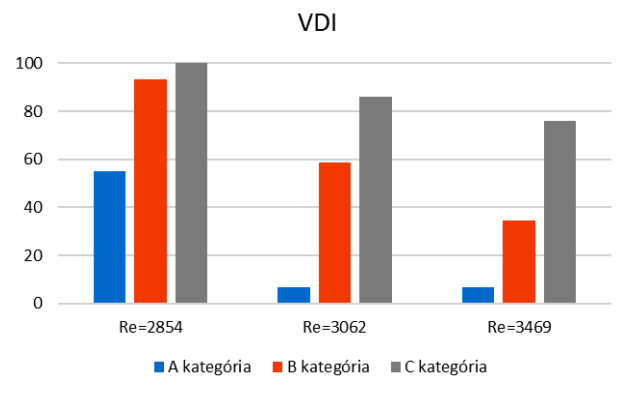

3. ábra. Velocity Distribution Index-ek a befúvási Reynolds-számok mellett

A beépítési távolság növelésével hasonló eredményt kaptunk derékmagasság felett, de a bokaszinten nem ez a jellemzö, ahol a VDI változása véletlenszerünek tünik [7].

\section{Következtetések}

Megállapítható, hogy a kisméretü irodahelyiség tartózkodási zónájában mért sebesség és turbulencia-fok átlaga többnyire jelentősen eltér a huzatkomfort szabványokban megadott értékhez képest. Az eltérés oka elsősorban ott keresendő, hogy a szabványok és müszaki ajánlások általánosságban, többnyire a helyiség rendeltetésének megfelelően adnak tervezési irányértékeket. Nem veszik figyelembe a helyiségben alkalmazott légvezetési rendszert, valamint ezen belül a befúvószerkezet típusát, geometriáját, elhelyezését és a többi befúvási jellemzöt, mint pl. a sebességet

\section{Szakirodalmi hivatkozások}

[1] CEN CR 1752:2000. Épületek szellöztetése. Épületek belsö környezetének tervezési alapjai.

[2] P.O. Fanger, A. K. Melikov, H. Hanzawa és J. Ring: Airflow characteristics in occupies zone of ventilated spaces, ASHRAE Trans, Vol. 93, Part 1, 1987, pp. 524-539.

[3] EN ISO 5167-1:2003. Anyagárammérés nyomáskülönbség elvén müködö eszközökkel olyan kör keresztmetszetü csővezetékben, amelyet az áramló anyag teljes keresztmetszetében kitölt. 1. rész: Alapelvek és alapkövetelmények.

[4] EN 13779:2007. Nem lakóépületek szellöztetése. Helyiségek szellöztetö és légkondicionáló rendszereinek teljesitménykövetelményei

[5] Bánhidi, L. és munkatársai: Épületgépészet a gyakorlatban, Verlag Dashöfer Kiadó, Budapest, 2004.

[6] Kemény, S., Deák, A.: Kisérletek tervezése és értékelése. Müszaki Könyvkiadó, Budapest, 2000.

[7] Both, B., Böttger, E.: Kisméretü irodahelyiség huzatkomfortjának elemzése és az eredmények összehasonlitása a nemzetközi szabványok elöírásaival. Magyar Épületgépészet, Budapest, 2016, 65:(11) pp. 9-12.

[8] Böttger E.: Érintöleges légvezetési rendszer légmozgásának méréses elemzése, TDK dolgozat, Budapest, 2016. 